Poznań

\title{
Political science in the Federal Republic of Germany \\ - featured examples ${ }^{1}$
}

\begin{abstract}
This paper presents the history of German political science and its current status. It contains a comparison of modern Political Science majors offered by the three top rated universities in German rankings - the University of Potsdam, Free University of Berlin and Humboldt University. It outlines the structure of political science studies, the type of courses offered and the literature used during teaching.
\end{abstract}

Key words: political science, science, university, Germany

T

he history of German political science is full of gaps and complexities. This is already reflected in the name of this discipline, which went through numerous evolutions: from "Politics" to "Teaching Politics,"3 and later in the Federal Republic of Germany, to "Science of Politics," "Scientific Politics,"5 "Political Science,"6 "Politics"7 and finally "Political Science" (Politikwissenschaft; Bleek, 2001, pp. 18-19).

The shape of today's German political science was strongly influenced by the events of 1945. It does not mean, however, that there are no older foundations, which date back to the Middle Ages and which are inseparably connected with the creation of universities (Bleek, p. 9). Being aware of this fact, C. J. Friedrich, a political scientist who contributed to the re-rooting of this discipline in the FRG, stated that the "Science of Politics," through its long ideological tradition is "both the oldest and the youngest science of human society" (Friedrich, 1954, p. 325).

In the early modern period, politics became an independent science with its own chair at Protestant universities. Until the mid-nineteenth century, the core of politics survived in the writings of G. W. F. Hegel, F. Schleiermacher and F. C. Dahlmann in the form of the philosophical and historically-oriented, liberal-bourgeois science of constitutions.

1 This article has been written within the research project: „Podstawowa literatura przedmiotu a kształt współczesnej politologii. Political Science, Politische Wissenchaft i Politologija w ujęciu porównawczym" (DEC-2012/05/B/HS5/00597) - financed by the National Science Centre in Poland.

2 Ger. "Politik."

3 "Lehre von der Politik."

4 "Wissenschaft von der Politik."

5 Contrary to its name - "Wissenschaftliche Politik" - this scientific movement had nothing in common with making practical politics more scientific.

6 The notion "Politische Wissenschaft" is a direct translation of the English term "Political Science."

7 The term "Politologie" used to describe the major and the title of graduates from Berlin was proposed by 2 political scientists - E. Fischer-Baling and G. von Eynern.

8 The term "Politikwissenschaft," as the most relevant to the content, and as being the most accurate in linguistic terms, was first used at the end of the twentieth century. At the same time it should be noted that what was formerly known as teaching of political science has little in common with today's political science, it can, however, help to understand its shape. 
As the involvement of these "political" professors crossed far beyond the framework of teaching, it became a turning point in the public perception of the political importance of political science in Germany. Despite this fact, at the end of the century, this respected and influential university discipline disappeared from university subjects in the German Empire. However, it still influenced some related courses, such as civil law, knowledge of history and national economics. What is more, it influenced the formation of the new political science abroad, mainly the creation of political science in the United States. The abolition of political science in the Empire was associated primarily with the change of the perception of science in general - at that time a big emphasis was placed on natural sciences which had their own autonomous research methods. The interdisciplinary and normative "Teaching politics," which referred to this practice, did not fully meet these requirements. Also the change in the political culture of Germans, associated with the creation of the Second Reich, played an important part in this phenomenon. Politics came to be associated with practice in internal and external dimensions (with competent administrators and statesmen) and not with the academic subject (Politikwissenschaft).

After the founding of the Weimar Republic, the idea of restoring politics to the rank of an academic subject - C. H. Becker - and the need for the democratic education of the political elite - M. Weber, F. Neumann - were strongly emphasized. As, in the end, the return of this academic major proved impossible, the focus was placed on the German School of Politics founded in 1920 in Berlin. ${ }^{9}$ This school served several functions, including that of an academic higher educational institution with its own research department in the years 1927-1933. After the National Socialists took power, it was incorporated in 1940 into the Faculty of Foreign Studies at Friedrich Wilhelm University ${ }^{10}$ and politicized in the spirit of Nazi ideology, which resulted in the fact that most of its lecturers went into exile (Politikwissenschaft).

The return of politics as an academic major took place in the fifties in democratic West Germany because, according to C. J. Friedrich, "«Science of Politics» can only thrive in a free country" (Friedrich, p. 325). The chairs were occupied mostly by teachers returning from exile and those who survived under the Hitler government (Politikwissenschaft). Since many of them had worked in the United States, they transferred the method and pattern of issuing political science books and journals onto German soil. Some of the most important publications were "Deutsche Vereinigung für die Wissenschaft von der Politik" and "Politische Vierteljahresschrift" (Politikwissenschaft).

West German "Science of Politics" identified itself as a democratic science. Within its framework, the universities sought to deal with the recent past, thus they raised issues concerning the political and historical events which enabled the re-rooting of democracy in West Germany, as well as theoretical and empirical democracy, including research on parliamentarism, political parties and elections, the creation of the German Democratic Republic and Communist dictatorship. Both the number of departments and students grew rapidly - in 1960 there were 18 universities, 24 Chairs of "Political Science" (including 10 chairs at the Centre for Teaching and Research in Political Science at the Free University of Berlin), 5 years later, there were 51, and in 1975 already 133 (Politikwissenschaft).

${ }^{9}$ Deutsche Hochschule für Politik-DHfP. The resurrection of DHfP as a non-academic Institution took place in 1948.

${ }^{10}$ Friedrich-Wilhelms-Universität was renamed in 1949 on the Humboldt-Universität zu Berlin. 
The vast expansion of this major in the sixties and seventies contributed to its crisis - the uniformity and scientific integrity of political science was put to the test. The dispute over leadership theory - normative-ontological, empirical-analytical or dialecticcritical - escalated, as well as the struggles between political camps intensified: between restaurateurs, conservatives (supporters of the system) and revolutionaries (progressive ones) (Politikwissenschaft).

The normative-ontological approach was oriented towards the western tradition of ancient philosophy and treated "Political Science" as a part of applied philosophy. Its representatives were looking for the ultimate goal of policy and standards in politics, a good and fair political order, and timeless values (e.g. truth, goodness and justice) through reflection and philosophical analysis. The normative-ontological theory was represented by the Freiburg School ${ }^{11}$ and the Munich School, whose representatives were: A. Bergsträsser, F. Böhm, W. Eucken, W. Hennis, K. F Maier, F. W. Meyer, L. Strauss and E. Voegelin (Entstehung). Normativity, in this approach, was connected with referring not only to the existing empirical political reality (and its scientific analysis), but also to political action aimed at specific goals and goodness, so that the active human could attain the necessary fulfillment of his/her existence. In contrast, the ontological component referred to the assumption that there must be a sense to human existence and the order of perception (Naßmacher, 2010, pp. 531-532; Bleek, pp. 337-341).

Empirical and analytical theory tried to investigate political phenomena with the methods typical of natural sciences. The attempt to describe more accurately all political events and their causes, as well as the strict separation of values in statements from those relating to facts were inextricably linked with this understanding of "Political Science." This approach was represented by the Cologne-Mannheim School ${ }^{12}$ whose representatives were: F. A. Hermens, W. Kaltefleiter and J. A. Schumpeter (Detjen; Die Anfänge). They assumed that by the systematically and methodically controlled observation of reality it is possible to discover the relationships between social phenomena. The empirical side of this approach was associated with a conviction that all claims relating to the characteristics of society and politics must be verifiable through intersubjective experience (observation) if they want to be considered knowledge. On the other hand, the analyticity of this approach was connected with the assumption that the conceptual and logical order and analysis of observational data are the key elements of scientific study. In addition, it postulated that different expression in science should be logically consistent (Naßmacher, pp. 534-536; Bleek, pp. 360, 382).

The dialectic critical approach (dialectic and historical) was based on the combined idealistic philosophy of G. W. F. Hegel and the historical-materialist philosophy of K. Marx (there were numerous variations of this approach). It was represented by

${ }^{11}$ In 1948 W. Eucken and F. Böhm created the magazine "ORDO - Jahrbuch für die Ordnung von Wirtschaft und Gesellschaft." It became the main forum of exchange of points of view of all supporters of ordoliberalism.

${ }_{12}$ Within the framework of the Cologne University Research Institute of Political Sciences and European Issues (Forschungsinstituts für Politische Wissenschaft und Europäische Fragen), established in 1960, and thanks to the involvement of F. A. Hermens, the new journals, "Kölner Schriften zur Politischen Wissenschaft, Demokratische Existenz heute, Demokratie und Frieden" and "Jahrbuch Verfassung und Verfassungswirklichkeit," were published. 
the Frankfurt School ${ }^{13}$ and the Marburg School, ${ }^{14}$ but it also had many representatives at other universities (Buckel, Fischer-Lescano, Hanschmann, Lothar, p. 171). Among them, the most important were: W. Abendroth, T. W. Adorno, E. Fromm, M. Horkheimer, O. Kirchheimer, L. Löwenthal, H. Marcuse and F. Neumann. At the center of this theory were such concepts as the dialectic, totalitarianism, opposition, alienation and fetishization. Representatives criticized the previous positivist knowledge drawn from experience, which reduced knowledge to purely technical usable knowledge. Also, the Catholic doctrine on politics was criticized as "bourgeois political science" and as the uncritical science of domination. This approach presented the new understanding of "critical political science" as "the science of opposition" towards the political system of the Federal Republic of Germany. By rejecting the achievements of other theorists, representatives of this approach demanded a monopoly on scientific research policy, which, among others, resulted in them being blocked on the academic job market due to being considered as radical revolutionaries, opposed to the system (Bleek, pp. 360-362; BergSchlosser, Stammen, Munich 2003, pp. 60-80).

At the end of the sixties, as a result of the so-called "student protests," 15 neo-Marxist and anarchist ideas became well known to German public opinion, which began to identify those ideas with the entire group of political scientists. As a result, political scientists were labeled as critics of the system, and revolutionaries who were undermining the state whose support they used. The more political than scientific confrontations conducted between supporters of various theories led, among other things, to the fact that in 1983 more traditionally oriented professors separated themselves scientifically and politically from the German Union of Political Science ${ }^{16}$ (Politische Vierteljahresschrift - PVS; DVPW, Rundbriefe) and formed the German Association of Political Science ${ }^{17}$ (Details; Deutsche Gesellschaft für Politikwissenschaft - DGfP, Veröffentlichungen). The younger, politically moderate and scientifically ambitious professors tried to counter the crisis ${ }^{18}$ through the new placement of West-German "Politics" in the canon of academic subjects. They sought therefore to describe its theoretical efforts and methodological tools as "modern social science" (Politikwissenschaft).

The addition of a large new field of research was closely related to the modern understanding of political science as a discipline of empirical social research: in addition to the analysis of polity in the institutional framework and research concerning politics as a process, the study of policies also joined the current, as the area and the effects of

13 In 1986, law students associated with the school started to publish a journal "Kritische Justiz. Vierteljahresschrift für Recht und Politik," which became a forum for new social movements.

${ }^{14}$ In 1960 W. Abendroth started to publish "Marburger Abhandlungen zur politischen Wissenschaft." This series was substituted by "Schriftenreihe des Instituts für wissenschaftliche Politik" published since 1955.

15 The protests, attended by, among others, students, lecturers and some professors, were an expression of the wider rebellion against the older generation and its achievements.

16 Since 1960, the Union has been publishing the journal "Politische Vierteljahresschrift - PVS." Members of Deutsche Vereinigung für Politische Wissenschaft (DVPW) can also publish in "Politikwissenschaft. Rudnbrief der Deutschen Vereinigung für Politische Wissenschaft."

17 The Association (Deutsche Gesellschaft für Politikwissenschaft - DGfP) has, since 1988, been publishing the series "Veröffentlichungen der Deutschen Gesellschaft für Politikwissenschaft (DGfP)."

${ }_{18}$ Currently the majority of political scientists are members of both DVPW and DGfP. 
public action. The labor market, education policy, health, social affairs, environmental protection and many other policy areas became not only an area of political scientific research, but also became an area of intensified political advice. Thanks to this fact, by the late twentieth century, West German "Politics," in the eyes of society and from the perspective of other scientific disciplines, was considered as a fully-fledged science, whose existence and position were no longer questioned (Politikwissenschaft).

After German reunification, due to institutional and staff shortcomings, ${ }^{19}$ not only West-German guest professors but also the West-German model of teaching, including the division of political science into four chairs: Political theory and the history of ideas, German System of Government, International politics and German foreign policy, were transferred to the former East German universities. This allowed for the emergence of political science at these universities and up to 1995 for 53 chairs to be filled. Just as in West Germany, the science of politics in the former East Germany was described as democratic (Politikwissenschaft).

Political science studies in the united Germany have a three-tier system - Bachelor, as a rule, lasts 3 years (6 semesters), Master 2 years (4 semesters), PhD 3-5 years ${ }^{20}$ (Brandenburgisches; Verordnung über die Gestaltung von Prüfungsordnungen, Prüfungen und Abschlüssen). The State and the States of Germany have jointly developed fundamental and structural issues concerning the offer of majors, taking into account progress in science, professional practice and the system of higher education (Hochschulrahmengesetz, 2. Abschnitt Studium und Lehre, $\$ 9$ Koordinierung der Ordnung von Studium und Prüfungen). Universities, however, are granted the right to create undergraduate and graduate majors and courses (Hochschulrahmengesetz). Teaching is carried out according to the standards which, in the case of the university, are determined, above all, at the States of Germany leve ${ }^{21}$ (Hochschulrahmengesetz, 6. Kapitel Anpassung des Landesrechts). According to the Framework Law of Universities - HRG ${ }^{22}$ universities are granted the freedom, among others, of determining the basic regulations (however, they require the approval of the relevant State of Germany) and in the area of research and teaching. Freedom of scientific research includes, in particular, the issue of rules of methodology and evaluation of the results of research, and its dissemination. By contrast, freedom of teaching includes, first and foremost, conducting classes, their content and methodology, as well as the right to express scientific views (Hochschulrahmengesetz, 4. Kapitel Rechtsstellung der Hochschule, 1. Abschnitt Allgemeine Bestimmungen, $\S 4$ Freiheit von Kunst und Wissenschaft, Forschung, Lehre und Studium). These rights were confirmed in the Laws on Higher Education of various States of Germany (Berliner Hochschulgesetz, Erster Abschnitt Einleitende Vorschriften, $\$ 2$ Rechtsstellung, $\$ 5$ Freiheit der Wissenschaft und Kunst; Brandenburgisches Hochschulgesetz, \& 5 Rechtsstel-

${ }^{19}$ In the GDR "Politics" was practically non-existent. For many years, only Marxism-Leninism was taught. After the unification, attempts were made to eliminate these shortcomings by renaming departments (to political science) and staff (to political scientists).

${ }^{20}$ The length of doctoral studies depends on both their form ("classical" doctoral studies are associated with individual work on a dissertation under the guidance of an academic supervisor; others of the kind are studies related to a specific doctoral program; studies in doctoral colleges become increasingly popular) as well as on the arrangements of particular State of Germany.

${ }^{21}$ Only a few issues (related to admission to study) are required to match federal law.

${ }^{22}$ Hochschulrahmengesetz-HRG. 
lung; Aufsicht, $\S 4$ Freiheit von Lehre, Forschung und Studium in Wissenschaft und Kunst; wissenschaftliche Redlichkeit).

The connection of education with subsequent professions is strongly emphasized in the German system of higher education. According to HRG, "teaching and research are to prepare students for professional activity and so to pass specific knowledge, skills and methods appropriate for each course so that they are able to perform scientific or artistic work and to act responsibly in a free, democratic and social state of law" (Hochschulrahmengesetz, 2. Abschnitt Studium und Lehre, $\& 7$ Ziel des Studiums). In addition, universities have the permanent task of checking and expanding (in collaboration with relevant government agencies) the content and form of studies, among others, due to the needs of professional practice and necessary changes in the professional world (Hochschulrahmengesetz, 2. Abschnitt Studium und Lehre, \& 8 Studienreform).

Due to all these provisions, a vast range of political science majors exist in German universities. As presenting of all of them would go far beyond the scope of this paper, the undergraduate courses of study that are in the top positions in the German rankings offered by the University of Potsdam, Free University of Berlin and Humboldt University in Berlin ${ }^{23}$ will be described below.

\section{Political science at the University of Potsdam}

The Faculty of Economic and Social Sciences was established in 1991, as was the University of Potsdam ${ }^{24}$ (Wefers, 2007, p. 116). Despite the fact of being a very young faculty, its interdisciplinary courses of study, combining politics with the administration, organization and economy, were assessed highly by the Centre for Higher Education Development $^{25}$ in 2012/2013 Ranking of Excellence ${ }^{26}$ (CHE).

This faculty tries to combine an excellent academic reputation with the proximity of government institutions, associations and research institutions, and consultancy in Potsdam and Berlin (Bachelor Politik und Verwaltung). Professors of political science and administration and docents and guest professors are responsible for teaching and research in seven chairs. In contrast, practical knowledge is provided, among others, by representatives of the Bundestag and the federal government, who are integrated into teaching through repeatedly held classes (Fachgruppe). According to a ranking con-

${ }^{23}$ Most of the political science majors analyzed in the paper are offered as basic, additional or parallel studies. The authors focused on presenting political science as the basic bachelor's major.

${ }^{24}$ The University was established on the basis of the Brandenburg Academy of Federated State in Potsdam (Brandenburgische Landeshochschule Potsdam) and Potsdam-Babelsberg School of Law and Administration (Hochschule für Recht und Verwaltung Potsdam-Babelsberg) existing since 1948.

25 "Centrum für Hochschulentwicklung" - CHE.

${ }^{26}$ The Ranking of Excellence consists of four parts: 1. ranking of universities, 2. ranking of research institutions, 3. ranking of excellence, 4. ranking of "employability." It allows outstanding institutes/ faculties in Europe to be identified and presents detailed information about the study programs offered, among others, in political science majors. Units belonging to the "Excellent Group" are determined by several criteria: 1 . number of publications, 2 . number of citations, 3. outstanding scientists, 4. number of projects completed under the Marie Curie program 5. internationalization of universities (based on the educational program Erasmus Mundus and the degree of mobility of students and lecturers). 
ducted in 2007, which was attended by members of the DVPW and DGfP, the university was among three leading universities and research institutions conducting research in the field of Politics and Administration ${ }^{27}$ (IX., 5. Die Reputation von Universitäten und Forschungsstätten, p. 154). Moreover, Prof. Dr. W. Jann received 2nd place in the category of the most important representative of the discipline ${ }^{28}$ (IX., p. 156).

Political scientists working in the department are not only involved at national and international level in various political advisory bodies, but also regularly publish research results in recognized national and international journals, and some of them are editors of journals and book series, for example, such as "West European Politics," "International Review of Administrative Sciences" or "International Comparative Social Studies" (Fachgruppe). In 1993, in cooperation with Polish scientists from the Western Institute in Poznan, Potsdam political scientists founded the magazine "WeltTrends." Problems of German foreign policy at the beginning of the twenty-first century are discussed and analyzed on its pages (WeltTrends). The analysis of published texts indicates that the academics of this department do not identify themselves with one specific theory of research, but empirical and analytical theory ${ }^{29}$ is highly commended.

Because no university regulations define the canon of literature compulsory for students, in practice, each lecturer working at the Faculty of Economic and Social Sciences selects the literature which is used during classes and required to pass exams or obtain credits. This means that in different academic years different works and articles can be discussed, even if the classes are taught by the same teacher, although it has been noticed that there are some components which usually appear on the list of required literature. ${ }^{30}$

In the obligatory area of the History of ideas and political theories, one can name the following publications: Aristotle (2010), Politik: Schriften zur Staatstheorie, ed. F. F. Schwarz, Stuttgart; Hobbes T. (1998), Leviathan: erster und zweiter Teil, J. P. Mayer (trans.), M. Diesselhorst - summary, Stuttgart; Hoerster N. (ed.) (1992), Klassische Texte der Staatsphilosophie, München; Stüwe K., Weber G. (eds.) and introduction (2004), Antike und moderne Demokratie: ausgewählte Texte, Stuttgart; Weber M. (1993), Politik als Beruf, R. Dahrendorf - summary, Stuttgart.

In the compulsory area of the German political system the following titles most commonly occur: Beyme K. (2004), Das politische System der Bundesrepublik Deutschland: Eine Einführung, Wiesbaden; Green S., Paterson W. E. (eds.) (2005), Governance in Contemporary Germany: The Semisovereign State Revisited, Cambridge; Hartmann J. (2004), Das politische System der Bundesrepublik Deutschland im Kontext. Eine Einführung, Wiesbaden; Hesse J. J., Ellwein T. (2004), Das Regierungssystem der Bundesrepublik Deutschland, Berlin; Schmidt M. G. (2011), Das politische System der Bundesrepublik Deutschland, Wiesbaden; Sturm R., Pehle H. (2005), Das neue deutsche Regierungssystem, Opladen.

${ }^{27}$ In the category Policy Forschung, Verwaltungswissenschaft.

${ }^{28}$ In the category Policy Forschung, Verwaltungswissenschaft.

${ }^{29}$ The authors reached this conclusion on the basis of research conducted on articles published in the pages of the journal "WeltTrends" co-created and edited by the Potsdam political scientists.

${ }^{30}$ Due to the very large number of classes offered to students of political science at the University of Potsdam, the Free University and Humboldt University, the authors focused on examining and comparing the literature required for lectures in three areas that exist as mandatory at all three universities. 
Furthermore, in the mandatory area of International politics, one can find the following publications: Baylis J., Smith S. (2006), The Globalization of World Politics. An Introduction to International Relations, Oxford; Bueno de Mesquita B. (2010), Principles of International Politics, Washington, DC; Carlsnaes W., Risse T., Simmons B. (eds.) (2012), Handbook of International Relations, London; Deutsch K. W. (1968), The Analysis of International Relations, Englewood Cliffs; Devetak R., Burke A., George J. (eds.) (2012), An Introduction to International Relations, Cambridge; Dougherty J. E., Pfaltzgraff R. L. (1996), Contending Theories of International Relations. A Comprehensive Survey, New York; Elsenhans H. (1984), Nord-Süd-Beziehungen. Geschichte - Politik - Wirtschaft, Stuttgart; Frieden J., Lake D., Schultz K. (eds.) (2013), World Politics. Interests, Interactions, Institutions, New York; Gilpin R. (1991), The Political Economy of International Relations, Princeton; Griffiths M. (1999), Fifty Key Thinkers in International Relations, London; Hall J. A., Paul T. V. (eds.) (1999), International Order and the Future of World Politics, Oxford; Hasenclever A., Mayer P., Rittberger V. (1997), Theories of International Regimes, Cambridge; Heywood A. (2011), Global Politics, London; S. Hoffman (ed.) (1960), Contemporary Theory in International Relations, Englewood Cliffs; Jackson R. J. (2013), Global Politics in the 21st Century, Cambridge; Schieder S., Spindler M. (2006), Theorien der Internationalen Beziehungen, Opladen; Smith S., Booth K., Zalewski M. (eds.) (1996), International Theory. Positivism and Beyond, Oxford; Vasquez J. A. (ed.) (1996), Classics of International Relations, London; Viotty P. R., Kauppi M. V. (1993), International Relations Theory. Realism, Pluralism, Globalism, New York.

In line with the foundation of interdisciplinary studies at this university, this department offers several undergraduate courses combining political sciences with administration, organization and economics (Wefers, p. 116; Die Wirtschafts).

a) Bachelor studies in Politics and Administration are the primary type of programs that lead to the first professional degree (bachelor). They last, as a rule, six semesters. During these studies, students gain interdisciplinary theoretical and methodological knowledge which enables the analysis of processes and political and administrative structures at different levels. Thanks to them, students also acquire decision-making skills and practice activities that are in demand in different areas of policy and administration, and in institutions and organizations, e.g. in political parties, public administration, NGOs and the mass media (Studienziele 1; Fachspezifische Ordnung 1, I. Allgemeiner Teil, § 4. Herb des Studiums).

The Bachelor program is divided into 5 areas - Basic studies, Deeper studies, Methods of empirical sociological research, Key competencies and Final modules. The classes assigned to Basic studies, for example: the History of ideas and political theories, Political system of Germany in the European context or Administration and public policy, are mandatory (to graduate, a student must receive 30 points $-\mathrm{LP}^{31}-$ from the module). The classes assigned to the area of deeper studies, for example: Political theory and political philosophy or International politics, are optional, and a student can choose from them (30 LP). The student must also obligatorily pass courses on Methods of empirical sociological research (12 LP), for example: Developing research questions and designing

${ }^{31}$ Leistungspunkte - LP. 
studies in politics and public administration, and also classes in Final modules (18 LP), which include, among others, the BA thesis (Fachspezifische Ordnung 1, II. Gestaltung des Bachelorstudiums, $\S 11$. Inhalt des Bachelorstudiums).

In addition, students must obtain the appropriate number of points (30 LP) from the Key competences, which are divided into a Basic phase and a Construction phase. The first of these includes a compulsory course - Basic political and administrative knowledge, as well as self-reflection and planning - and language, while the second phase includes a professional internship and courses provided under the "Studyplus." Internships are considered a central element of studies leading to a specific profession (12 LP). During at least six weeks of practice, students use the skills they have acquired in specific situations. Also they gain in knowledge of an organization and the functioning of various professions, which enables them later to select a place to work. The practical experience they gain may also become the basis for further education plans (Studienziele 1). Furthermore, "Studyplus," as a combination of complementary and interdisciplinary areas, familiarizes students with the key competencies of their chosen scientific discipline and provides insight into other areas and teaching methods in which they are encouraged to think in an interdisciplinary manner. The spectrum of knowledge is very wide - from language learning and intercultural competences, through the problems associated with digital processing of information, to the main problems of politics, religion, philosophy, government and society, the environment, energy and law. In this framework, the emphasis is placed on reflective thinking, coping with complex tasks and combining scientific knowledge with practical issues from different professional fields (Fachspezifische Ordnung 1, II. Gestaltung des Bachelorstudiums, § 10. Schlüsselkompetenzen).

After successful completion of the Politics and Administration major (gaining 120 LP), the student receives a Bachelor of Arts - BA university degree (Fachspezifische Ordnung 1, I. Allgemeiner Teil, § 5. Abschlussgrad).

Politics and Administration studies curriculum

\begin{tabular}{|l|c|}
\hline A) BASIC STUDIES/BASISSTUDIUM & 30 LP \\
\hline History of ideas and political theory/Ideengeschichte und politische Theorie & 6 \\
Political system of Germany in the European context/Politisches System Deutschlands im eu- & \\
ropäischen Kontext & 6 \\
Comparative political science/Vergleichende Politikwissenschaft & 6 \\
International politics/Internationale Politik & 6 \\
Administration and public policy/Verwaltung und Public Policy & 6 \\
\hline B) DEEPER STUDIES/VERTIEFUNGSSTUDIUM & $\mathbf{3 0 ~ L P}$ \\
\hline I: Political theory and political philosophy/Politische Theorie und Politische Philosophie & \\
\hline $\begin{array}{l}\text { Seminar in political theory and political philosophy/Vertiefungsseminar Politische Theorie und } \\
\text { Politische Philosophie }\end{array}$ & \\
$\begin{array}{l}\text { Seminar focused on researching political theory and political philosophy/Forschungsorientiertes } \\
\text { Vertiefungsseminar Politische Theorie und Politische Philosophie }\end{array}$ & 6 \\
\hline $\begin{array}{l}\text { II: Politics and governance in Germany and Europe/Politik und Regieren in Deutschland } \\
\text { und Europa }\end{array}$ & \\
\hline $\begin{array}{l}\text { Seminar in politics and governance in Germany and Europe/Vertiefungsseminar Politik und Re- } \\
\text { gieren in Deutschland und Europa }\end{array}$ & \\
$\begin{array}{l}\text { Seminar focused on research policy and governance in Germany and Europe/Forschungsorien- } \\
\text { tiertes Vertiefungsseminar Politik und Regieren in Deutschland und Europa }\end{array}$ & 6 \\
\hline
\end{tabular}




\begin{tabular}{|l|c||}
\hline III: Comparative political science/Vergleichende Politikwissenschaft & \\
\hline $\begin{array}{l}\text { Seminar in comparative political science/Vertiefungsseminar Vergleichende Politikwissenschaft } \\
\text { Seminar focused on comparative political research/Forschungsorientiertes Vertiefungsseminar } \\
\text { Vergleichende Politikwissenschaft }\end{array}$ & 6 \\
\hline IV: International politics/Internationale Politik & 6 \\
\hline $\begin{array}{l}\text { Seminar in international politics/Vertiefungsseminar Internationale Politik } \\
\text { Seminar focused on international politics/Forschungsorientiertes Vertiefungsseminar Internation- } \\
\text { ale Politik }\end{array}$ & 6 \\
\hline V: Administration and Public Policy/Verwaltung und Public Policy & 6 \\
\hline $\begin{array}{l}\text { Seminar in administration and public policy/Vertiefungsseminar Verwaltung und Public Policy } \\
\text { Seminar focused on administration and public policy/Forschungsorientiertes Vertiefungsseminar } \\
\text { Verwaltung und Public Policy }\end{array}$ & 6 \\
\hline $\begin{array}{l}\text { C) METHODS OF EMPIRICAL SOCIOLOGICAL RESEARCH/METHODEN DER EM- } \\
\text { PIRISCHEN SOZIALFORSCHUNG }\end{array}$ & $\mathbf{1 2 ~ L P}$ \\
\hline $\begin{array}{l}\text { Design and quantitative and qualitative data collection methods in sociological research/Design } \\
\text { und Methoden der Datenerhebung in der quantitativen und qualitativen Sozialforschung } \\
\text { Descriptive and statistical models of socio-scientific analysis of data/Deskriptiv- und inferenzsta- } \\
\text { tistische Modelle der sozialwissenschaftlichen Datenanalyse }\end{array}$ & 6 \\
\hline D) KEY COMPETENCES/SCHLÜSSELKOMPETENZEN & 6 \\
\hline Basic phase/Grundphase & $\mathbf{3 0 ~ L P}$ \\
\hline $\begin{array}{l}\text { Basic political and administrative knowledge, as well as self-reflection and planning/Grundlagen } \\
\text { der Politik- und Werwaltungswissenschaft sowie Selbstreflexion und Plannung } \\
\text { Foreign languages/Fremdsprachenkompetenz }\end{array}$ & 6 \\
\hline Construction phase/Aufbauphase & 6 \\
\hline $\begin{array}{l}\text { Professional internship/Berufspraktikum } \\
\text { Individual “Studyplus"/Individuelles Studiumplus }\end{array}$ & 12 \\
\hline E) FINAL MODULES/ABSCHLUSSMODULE & 6 \\
\hline $\begin{array}{l}\text { Developing research questions and designing studies in politics and public administration/Ent- } \\
\text { wicklung von Forschungsfragen und Forschungsdesigns in der Politik- und Verwaltungswissen- } \\
\text { schaft } \\
\text { BA thesis/Bachelorarbeit }\end{array}$ & $\mathbf{1 8 ~ L P ~}$ \\
\hline TOTAL/INSGESAMT & 6 \\
\hline
\end{tabular}

b) Politics, Administration and Organization is an interdisciplinary course leading to the first degree (bachelor). During these studies, students gain knowledge and skills in the field of political science, management, sociology and economics, among others, and learn about the history of political thinking and its importance for democracy. Thanks to the scientific basis, these studies provide knowledge of the theories, methods and regularities that are necessary to analyze political problems, understand the structural knowledge of the foundations and existing forms of governmental and social institutions, political parties and interest groups and that provide the directions of their activities. Students thoroughly familiarize themselves with current research areas such as research into political parties, modernization of management, international politics and policies, organization and management or civil society. In addition, these studies enable students to acquire social and personal competences required in the later work. Therefore, they are educated in decisionmaking skills and activities needed to perform the duties that arise in different areas of policy making and administration, and in the related institutions and organizations, for instance, in associations, parties, government organizations and mass media (Fachspezifische Ordnung 2). 
Studies, as a rule, last six semesters. The program is divided into five areas - Basic studies, Deeper studies, Internship or semester abroad, Key competencies and Final modules. The classes assigned to Basic studies, for example: History of ideas and political theories, Political system of Germany in the European context, Introduction to sociology of organization and administration or Empirical methods I, are mandatory (the student must obtain 60 LP). In contrast, activities in the area of Deeper studies, for example: Political theory and political philosophy, Administration and public policy and International organizations, are optional activities (42 LP). An integral part of the studies is to spend one semester at a foreign university or on internship, which serves to deepen and complement the competencies acquired during studies (30 LP). Practice lets students explore the practical aspects of work and helps them in later career choices (Fachspezifische Ordnung 2).

In addition, students are required to pass the Key competences area (30 LP) consisting of a Basic phase (compulsory) and a Construction phase (optional classes). Also during these studies students can find courses provided under the "Studyplus" (Schlüsselkompetenzen 1) among proposed activities, whereas the Final modules (18 LP) consist of a compulsory Colloquium in preparation for writing a BA thesis and the BA thesis itself (Fachspezifische Ordnung 2; Studienziele 2).

After successfully completing Politics, Administration and Organization (by gaining 180 LP), students receive a Bachelor of Arts - BA university degree (Fachspezifische Ordnung 2).

\section{Politics, Administration and Organization studies curriculum}

\begin{tabular}{|c|c|}
\hline A) BASIC STUDIES/BASISSTUDIUM & $60 \mathrm{LP}$ \\
\hline 1) Knowledge of politics and administration/Politik- \& Verwaltungswissenschaft & $30 \mathrm{LP}$ \\
\hline History of ideas and political theories/Ideengeschichte und politische Theorie & 6 \\
\hline $\begin{array}{l}\text { Political system of Germany in the European context/Politisches System Deutschlands im eu- } \\
\text { ropäischen Kontext }\end{array}$ & 6 \\
\hline Comparative political science/Vergleichende Politikwissenschaft & 6 \\
\hline International politics/Internationale Politik & 6 \\
\hline Administration and public policy/Verwaltung und Public Policy & 6 \\
\hline 2) Organization and management/Organisation und Management & $18 \mathrm{LP}$ \\
\hline $\begin{array}{l}\text { Introduction to sociology of organization and administration/Einführung in die Organisations- } \\
\text { und Verwaltungssoziologie }\end{array}$ & 6 \\
\hline Public management I: Basics/Public Management I: Grundlagen & 6 \\
\hline Introduction to organization, leadership and staff/Einführung in Organisation, Führung \& Personal & 6 \\
\hline 3) Methods of empirical sociological research /Methoden der empirischen Sozialforschung & $12 \mathrm{LP}$ \\
\hline Empirical methods I/Empirische Methoden I & 6 \\
\hline Empirical methods II/Empirische Methoden II & 6 \\
\hline B) DEEPER STUDIES/VERTIEFUNGSSTUDIUM & $42 \mathrm{LP}$ \\
\hline 1) Knowledge of politics and administration/Politik- und Verwaltungswissenschaft & $24 \mathrm{LP}$ \\
\hline $\begin{array}{l}\text { I: Political theory and political philosophy/Politische Theorie und Politische Philosophie } \\
\text { - Seminar in political theory and political philosophy/Vertiefungsseminar Politische Theorie } \\
\text { und Politische Philosophie } \\
\text { - Seminar focused on studying political theory and political philosophy/Forschungsorientiertes } \\
\text { Vertiefungsseminar Politische Theorie und Politische Philosophie }\end{array}$ & 6 \\
\hline $\begin{array}{l}\text { II: Politics and governance in Germany and Europe/Politik und Regieren in Deutschland und Europa } \\
\text { - Seminar in politics and governance in Germany and Europe/Vertiefungsseminar Politik und } \\
\text { Regieren in Deutschland und Europa } \\
\text { - Seminar focused on research policy and governance in Germany and Europe/Forschungsori- } \\
\text { entiertes Vertiefungsseminar Politik und Regieren in Deutschland und Europa }\end{array}$ & 6 \\
\hline
\end{tabular}




\begin{tabular}{|c|c|}
\hline $\begin{array}{l}\text { III: Comparative political science/Vergleichende Politikwissenschaft } \\
\text { - Seminar in comparative political science/Vertiefungsseminar Vergleichende Politikwissen- } \\
\text { schaft } \\
\text { - Seminar focused on research into comparative political science/Forschungsorientiertes Vertie- } \\
\text { fungsseminar Vergleichende Politikwissenschaft }\end{array}$ & 6 \\
\hline $\begin{array}{l}\text { IV: International politics/Internationale Politik } \\
\text { - eminar in international politics/Vertiefungsseminar Internationale Politik } \\
\text { - Seminar focused on research into international politics/Forschungsorientiertes Vertiefungsse- } \\
\text { minar Internationale Politik }\end{array}$ & 6 \\
\hline $\begin{array}{l}\text { V: Administration and public policy/Verwaltung und Public Policy } \\
\text { - Seminar in administration and public policy/Vertiefungsseminar Verwaltung und Public } \\
\text { Policy } \\
\text { - Seminar focused on research administration and public policy/Forschungsorientiertes } \\
\text { Vertiefungsseminar Verwaltung und Public Policy }\end{array}$ & 6 \\
\hline $\begin{array}{l}\text { VI: Methods of empirical sociological research/Methoden der empirischen Sozialforsc- } \\
\text { hung } \\
\text { - Empirical methods III/Empirische Methoden III } \\
\text { - Empirical methods IV/Empirische Methoden IV }\end{array}$ & $\begin{array}{l}6 \\
6\end{array}$ \\
\hline 2) Organization and management /Organisation und Management & $18 \mathrm{LP}$ \\
\hline $\begin{array}{l}\text { Organization and management of staff/Organisation und Personalmanagement } \\
\text { Public management/Public Management } \\
\text { Process management and e-administration/Prozessmanagement und E-Government } \\
\text { Organization Studies } \\
\text { Methods of empirical social research/Methoden der empirischen Sozialforschung } \\
\text { Methods of empirical economic research/Methoden der empirischen Wirtschaftsforschung } \\
\text { Sociology of relations between the sexes/Soziologie der Geschlechterverhältnisse } \\
\text { Municipal policy/Kommunalpolitik } \\
\text { Policy field research/Politikfeldforschung } \\
\text { Government organizations/Regierungsorganisation } \\
\text { International organizations/Internationale Organisationen }\end{array}$ & $\begin{array}{l}6 \\
6 \\
6 \\
6 \\
6 \\
6 \\
6 \\
6 \\
6 \\
6 \\
6\end{array}$ \\
\hline $\begin{array}{l}\text { C) INTERNSHIP OR SEMESTER ABROAD/PRAKTIKUM ODER AUSLANDSSEMES- } \\
\text { TER }\end{array}$ & $30 \mathrm{LP}$ \\
\hline $\begin{array}{l}\text { Option I: Internship at home or abroad /Variante I: Praktikum im In- oder Ausland } \\
\text { Option II: Semester Abroad /Variante II: Auslandssemester }\end{array}$ & $\begin{array}{l}30 \\
30\end{array}$ \\
\hline D) KEY COMPETENCES/SCHLÜSSELKOMPETENZEN & $30 \mathrm{LP}$ \\
\hline Basic phase/Grundphase (12 LP) & \\
\hline $\begin{array}{l}\text { Compulsory modules:/Pflichtmodule: } \\
\text { Basics of political and administrative knowledge, as well as self-reflection and planning /Grund- } \\
\text { lagen der Politik- und Werwaltungswissenschaft sowie Selbstreflexion und Plannung } \\
\text { Foreign languages, or communication, presentation and mediation ("Studyplus")/Fremdspra- } \\
\text { chenkompetenz oder Kommunikation, Präsentation und Vermittlung (Studiumplus) }\end{array}$ & 6 \\
\hline Construction phase/Aufbauphase (18 LP) & \\
\hline $\begin{array}{l}\text { I. Selection module:/I. Wahlpflichtmodul: } \\
\text { Introduction to Economics/Einführung in die Volkswirtschaftslehre } \\
\text { State law for non-lawyers and Administrative Law for non-lawyers/Staatsrecht für Nicht-Juristen } \\
\text { und Allgemeines Verwaltungsrecht für Nicht-Juristen } \\
\text { II. Selection module:/II. Wahlpflichtmodul: } \\
\text { Individual "Studyplus"/Individuelles Studiumplus }\end{array}$ & 12 \\
\hline E) FINAL MODULE/ABSCHLUSSMODULE & $18 \mathrm{LP}$ \\
\hline $\begin{array}{l}\text { Colloquium in preparation for writing BA thesis/Kolloquium zur Vorbereitung auf die Bache- } \\
\text { lorarbeit } \\
\text { BA thesis/Bachelorarbeit }\end{array}$ & $\begin{array}{r}6 \\
12\end{array}$ \\
\hline TOTAL/INSGESAMT & $180 \mathrm{LP}$ \\
\hline
\end{tabular}


c) The Politics and Economy Bachelor ${ }^{32}$ offers extensive knowledge of political science and economics. Great emphasis is placed on the use of the skills acquired and methods of critical reflection, and the development of interdisciplinary approaches to political and economic problems. In addition, students acquire the necessary practice in professional soft skills: ability to work in teams, to report and defend scientifically valid opinions. Research competences are another key point of interdisciplinary research into politics and economics. The transfer of knowledge in the field of statistics and methodology therefore plays an important role in this major (Bachelor of Science Politik \& Wirtschaft).

These studies enable the student to work in areas that require comprehensive scientific knowledge concerning politics and economy, analytical skills, good knowledge of methods and interdisciplinary problem-solving skills. Thus they allow graduates to work in national and international organizations and institutions operating in the field of politics and economics. In addition, they open up career opportunities in public administration, state and national ministries, in chambers of commerce, in political parties, associations, foundations and media and education sectors. Graduates of these studies will also be able to find jobs in research institutes and such related (Bachelor of Science Politik \& Wirtschaft).

Studies are divided into four areas - Politics, Economy, Basic Methods and Key competencies. Politics includes lectures in the field of politics and public administration (the student must obtain 54 LP). As part of the compulsory subjects of Basic studies, for example: the History of ideas and political theories, students can gain a wide knowledge of, among others, the basics of democracy, international regulations, legislative powers of the States of Germany (30 LP). As part of the elective modules in the field of Deeper studies, students can set their own research priorities, and thus develop an individual profile in their studies (24 LP). They increase their knowledge in different areas of policy and public administration, or specialize in specific policy areas, for instance public policy (Studienziele 3). As part of the seminars focused on research, students expand their skills in the use of scientific methods. The purpose of these activities, for example in Politics and governance in Germany and Europe, is to stimulate students' interest concerning current research topics and promote their research skills. The aim is not only to teach skills related to politics. During the seminars, students acquire skills such as independence, creativity, analytical and communication skills (Studienziele 3).

In the area of Economics, students gain comprehensive knowledge and skills in the field of economics (54 LP). During the mandatory classes on Basic studies, for example in Microeconomics I, students gain extensive basic knowledge (30 LP), while the optional courses offered in the Deeper studies, such as for example, International economic policy I, allow them to identify research priorities (24 LP). In this framework students can choose topics that are related to their personal interests, as well as are a useful supplement of the Policy area (Studienziele 3).

An in-depth knowledge of methods is required for the analysis of economic and political issues in order to be able to solve problems. In the area of Basic methods, students expand their math skills and acquire comprehensive knowledge in the field of statistics

\footnotetext{
${ }^{32}$ Politik und Wirtschaft - studies offered since academic year 2013/2014.
} 
and empirical economic research methods (24 LP). Thanks to classes such as Empirical economic research, students should be able to carry out empirical analysis. Teaching of research methods is carried out through courses, during which students learn the techniques of scientific work, as well as work with statistical software Stata (Studienziele $3)$.

In addition to the techniques of scientific research and other basic academic skills, in the area of Key competencies students acquire interdisciplinary knowledge and skills (30 LP). As part of Specific professional competence, students choose classes from the "Studyplus" offer. This means they can develop, for example, language skills, and gain knowledge in the area of law. In addition, through a multi-week internship, students gain practical experience, as well as insight into various sectors and professional areas. An internship can take place at home or abroad. It can take place in research institutions, mass media, public administration, political parties, national and international non-profit associations and non-governmental organizations (Schlüsselkompetenzen 2).

After successfully completing Politics and Economy studies (gaining 162 LP), the student receives a Bachelor of Science - BS university degree (Studienziele 3).

\section{Politics and Economy studies curriculum}

\begin{tabular}{|l|c|}
\hline A) POLITICS/POLITIK & 54 LP \\
\hline 1) Basic studies compulsory modules/Basisstudium Pflichtmodule & $\mathbf{3 0 ~ L P}$ \\
\hline History of ideas and political theories/Ideengeschichte und politische Theorie & 6 \\
Political system of Germany in the European context/Politisches System Deutschlands im eu- & \\
ropäischen Kontext & 6 \\
Comparative political science/Vergleichende Politikwissenschaft & 6 \\
International politics/Internationale Politik & 6 \\
Administration and public policy/Verwaltung und Public Policy & 6 \\
\hline 2) Deeper studies modules to choose from/Vertiefungsstudium Wahlpflichtmodule & $\mathbf{2 4 ~ L P}$ \\
\hline Area I: Political theory and political philosophy/Bereich I: Politische Theorie und Politische Philosophie & \\
- Seminar/Vertiefungsseminar & 6 \\
- Seminar focused on research/Forschungsorientiertes Vertiefungsseminar & 6 \\
\hline Area II: Politics and governance in Germany and Europe/Bereich II: Politik und Regieren in & \\
Deutschland und Europa & \\
- Seminar/Vertiefungsseminar & 6 \\
- Seminar focused on research/Forschungsorientiertes Vertiefungsseminar & 6 \\
\hline Area III: Comparative political science/Bereich III: Vergleichende Politikwissenschaft & \\
- Seminar/Vertiefungsseminar & 6 \\
- Seminar focused on research/Forschungsorientiertes Vertiefungsseminar & 6 \\
\hline Area IV: International politics/Bereich IV: Internationale Politik & \\
- Seminar/Vertiefungsseminar & 6 \\
- Seminar focused on research/Forschungsorientiertes Vertiefungsseminar & 6 \\
\hline Area V: Administration and public policy/Bereich V: Verwaltung und Public Policy & \\
- Seminar/Vertiefungsseminar & 6 \\
- Seminar focused on research/Forschungsorientiertes Vertiefungsseminar & 6 \\
\hline B) ECONOMY/WIRTSCHAFT & $\mathbf{5 4 ~ L P ~}$ \\
\hline 1) Basic studies compulsory modules/Basisstudium Pflichtmodule & $\mathbf{3 0 ~ L P ~}$ \\
\hline Introduction to Economics /Einführung in die Volkswirtschaftslehre & 6 \\
Microeconomics I/Mikroökonomie I & 6 \\
Microeconomics II/Mikroökonomie II & 6 \\
Macroeconomics I/Makroökonomie I & 6 \\
Macroeconomics II/Makroökonomie II & 6 \\
\hline
\end{tabular}




\begin{tabular}{|c|c|}
\hline 2) Deeper studies optional modules/Vertiefungsstudium Wahlpflichtmodule & 24 LP \\
\hline $\begin{array}{l}\text { Area I: Public sector, financial and social policy/Bereich I: Öffentlicher Sektor, Finanz- und } \\
\text { Sozialpolitik } \\
\text { - Public economics/Public Economics } \\
\text { - State and allocation/Staat und Allokation } \\
\text { - Seminar on chosen topic/Seminar zu ausgewählten Themen }\end{array}$ & $\begin{array}{l}6 \\
6 \\
6\end{array}$ \\
\hline $\begin{array}{l}\text { Area II: International economy/Bereich II: Internationale Wirtschaft } \\
\text { - International economic policy I/Internationale Wirtschaftspolitik I } \\
\text { - International economic policy II/Internationale Wirtschaftspolitik II } \\
\text { - Seminar on chosen topic/Seminar zu ausgewählten Themen }\end{array}$ & $\begin{array}{l}6 \\
6 \\
6\end{array}$ \\
\hline $\begin{array}{l}\text { Area III: Market and Competition/Bereich III: Markt und Wettbewerb } \\
\text { - Politics and competition theory/Wettbewerbstheorie und -politik } \\
\text { - Economic policy/Wirtschaftspolitik } \\
\text { - Seminar on chosen topic/Seminar zu ausgewählten Themen }\end{array}$ & $\begin{array}{l}6 \\
6 \\
6\end{array}$ \\
\hline C) BASIC METHODS/BASISMETHODEN & \\
\hline 1) Compulsory modules/Pflichtmodule & $18 \mathrm{LP}$ \\
\hline $\begin{array}{l}\text { Mathematics for economists 1/Mathematik für Wirtschaftswissenschaftler } 1 \\
\text { Statistics/Statistik } \\
\text { Empirical economic research/Empirische Wirtschaftsforschung }\end{array}$ & $\begin{array}{l}6 \\
6 \\
6\end{array}$ \\
\hline 2) Optional modules/Wahlpflichtmodule & $6 \mathrm{LP}$ \\
\hline $\begin{array}{l}\text { Seminar on a selected topic concerning empirical economic research/Seminar zu ausgewählten } \\
\text { Themen der empirischen Wirtschaftsforschung } \\
\text { Seminar on a selected topic concerning empirical social research/Seminar zu ausgewählten } \\
\text { Themen der empirischen Sozialforschung }\end{array}$ & 6 \\
\hline D) KEY COMPETENCES/SCHLÜSSELKOMPETENZEN & \\
\hline $\begin{array}{l}\text { 1) Academic competence compulsory core modules/Akademische Grundkompetenzen Pfli- } \\
\text { chtmodule }\end{array}$ & $12 \mathrm{LP}$ \\
\hline $\begin{array}{l}\text { Introduction to scientific work and self-reflection and planning/Einführung in das wissenschaftli- } \\
\text { che Arbeiten sowie Selbstreflexion und Planung } \\
\text { Introduction of computer-assisted data analysis/Einführung in die computergestützte Datenana- } \\
\text { lyse }\end{array}$ & 6 \\
\hline $\begin{array}{l}\text { 2) Specific professional competence modules to choose from/Berufsfeldspezifische Kompe- } \\
\text { tenzen Wahlpflichtmodule }\end{array}$ & $18 \mathrm{LP}$ \\
\hline $\begin{array}{l}\text { Foreign languages/Fremdsprachen (insbesondere der Erwerb von Englischkenntnissen auf dem } \\
\text { Niveau C1 des Gemeinsamen Europäischen Referenzrahmens) } \\
\text { Mathematics for economists 2/“Mathematik für Wirtschaftswissenschaftler 2“" } \\
\text { Law/Rechtswissenschaft } \\
\text { Professional internship/mehrwöchiges Berufspraktikum }\end{array}$ & \\
\hline TOTAL/INSGESAMT & $162 \mathrm{LP}$ \\
\hline
\end{tabular}

\section{Political science at the Free University of Berlin}

The Otto Suhr Institute for Political Science emerged in 1959 from the German School of Politics (DHfP) founded in 1920. As a result of the inclusion of the DHfP to the Free University of Berlin, postgraduate studies were replaced by full-time studies ending with receiving the diploma. The Institute originally took the form of an "interdepartmental" institution with the faculties of philosophy, economics and law. Thanks to the commitment of, among others, E. Fraenkel, F. Neumann and O. Stammer it developed its own scientific profile - of political science as an independent scientific discipline being at the center of teaching and research (Geschichte und Profile). In the years 
1969-1978 the Institute issued a journal "Sozialistische Politik (1969)," which became a forum for exchanging views of different factions of the New Left. In 1971, part of the editors began to formulate a new left-wing magazine - "PROKLA Zeitschrift für kritische Sozialwissenschaft" - which is still issued today (Heinrich; PROKLA Zeitschrift für kritische Sozialwissenschaft). Looking at the articles present in this publications, it can be easily observed that until the nineties many political scientists from the Otto Suhr Institute identified themselves with the critical-dialectical theory. At the moment, empirical-analytical and constructivist theory ${ }^{33}$ are most commonly used in studies. After the reunification of Germany, the Institute underwent a restructuring process, which was partly introduced in order to reduce the amount of chairs by half (currently 14). Despite this fact, it still remains one of the greatest political and scientific institutes within the Federal Republic of Germany (Geschichte und Profile).

The Institute conducts multidisciplinary integrated research as part of two out of three Excellence Initiative ${ }^{34}$ funding lines (Cluster of excellence "Languages of Emotions" and postgraduate schools), in the field of management (SFB 700 management in areas of limited statehood ${ }^{35}$ ), environment, on Europe, and areas outside Europe (Exzellenzinitiative; Über den SFB). Another distinctive feature of the Institute is the extent of the regional studies department, which is represented by the John F. Kennedy Institute for North American Studies, Institute for Latin American Studies, Institute for East European Studies, workshop "Politics in the Middle East" as well as ethnological and political studies of Asian and African key issues. Regional scientific research and teaching activities are also held in the Center for Area Studies, which is a key element of an international university network (Politikwissenschaft - Bachelor).

The Otto Suhr Institute, together with Paris Institute of Political Studies, offers students two versions of integrated binational study programs: a vocational version of the program - an integrated bachelor course in Political science at the Free University of Berlin (BA or diploma) and magister studies, Master of Political science at the Paris Institute - and also a research-oriented version of the program - which is an integrated master's studies in International relations run by the Free University of Berlin, Humboldt University and the University of Potsdam, and a master's degree, Master of International relations led by the Paris Institute (Politikwissenschaft - Bachelor).

These studies were highly rated in the Ranking of Excellence conducted by CHE in 2012/2013 (CHE). Furthermore, according to the ranking carried out in 2007, which was attended by members of DVPW and DGfP, FU received 1st place in the field of International Relations and 3rd place in the field of Political sociology (IX., 5. Die Reputation von Universitäten und Forschungsstätten, p. 154).

${ }^{33}$ Authors arrived to this conclusion through analyzing texts published in both journals.

${ }^{34}$ Exzellenzinitiative is a leading German university funding program under three lines: graduate school (Graduiertenschule), Clusters of excellence (Exzellenzcluster) and future projects (Zukunftskonzepte).

${ }^{35}$ SFB 700 Management in areas of limited statehood (SFB 700 Governance in Räumen begrenzter Staatlichkeit) is a research organization funded by the German Research Community (Deutschen Forschungsgemeinschaft - DFG), involving five partner institutions: the Free University of Berlin, University of Potsdam, Science and Politics Foundation (Stiftung Wissenschaft und Politik - SWP), Social Science Research Center in Berlin (Wissenschaftszentrum Berlin für Sozialforschung - WZB) and German Institute of Global and Area Studies - GIGA. 
Students of Political science bachelor studies become acquainted with the basic theoretical, methodological and empirical knowledge about the material, conceptual and normative foundations of politics. They receive knowledge about different political actors, processes and structures, as well as about various forms and functions of political and social systems, institutions at regional, national, international and global level. They become acquainted with the most important ideological, material and institutional factors upon which the activities of political parties, and thus political processes and their consequences depend on (or are formed by) (Studienordnung).

This expertise enables students to identify and scientifically and systematically describe the most important phenomena and political relations. They know how to structure, analyze, understand and explain these relationships in the light of the major theoretical and methodological approaches. They also have basic communication, organizational and presentation skills, which allow both individual and team research work. These competencies complement the intercultural competencies which, as being a didactic part of studies, offer instruments to diagnose problems concerning justice, equality and participation in political life, and their causes on personal, social, organizational, and structural grounds (Studienordnung).

The Political Science Bachelor major consists of two main areas - Basic course (the student must obtain $150 \mathrm{LP}$ ) and General area of professional preparation - $\mathrm{ABV}^{36}$ (30 LP). The first of these is further divided into: Introduction (28 LP), Basic area I (40 LP), Basic area II (20 LP), Area to choose from (specialization and tangential area) (30 LP), Deeper area (20 LP) and Colloquium and Bachelor's thesis (Studienordnung). Classes offered in the Introduction and basic Area I, for example, the Introduction to methods of scientific work or Theory, empiricism and history of international relations, are mandatory. There are optional classes in basic Area II, and optional activities in the Deeper area. These areas include different basic modules, specialized modules and deeper and tangential areas that extend the range of expert-scientific knowledge. At the end of the studies, the deepening and diversification of the chosen field of study begins through attendance of the Colloquium for one semester and independent research on a chosen issue within the framework of the thesis (12 LP) (Studienordnung).

The general area of professional preparation (30 LP) is divided into Professionally oriented modules in the area of additional qualifications (15 LP), Modules selected among other areas of competence (10 LP) and the Internship module (5 LP). ABV includes an internship and the following areas of competence: foreign languages, media literacy and information competence, competences related to gender theories and diversity, organizational and managerial skills, personal and social-communicative competence and related additional competences, which enable students to acquire additional practical knowledge and skills (Studienordnung).

The objectives, content and structure of the course of study and professional internship are governed by separate regulations. The structure and syllabus are found in the Studies Regulations. It contains detailed descriptions, the content and learning objectives of each module, and a sample study plan. There are also points concerning each area, as well as specified working time hours during the full studies (Prüfungsordnung).

\footnotetext{
${ }^{36}$ Studienbereich Allgemeine Berufsvorbereitung (ABV).
} 
Neither the study regulations nor other documents define the canon of compulsory literature for Political science bachelor students. Each teacher individually chooses the books and articles that are used and discussed in class, and required for the exam. This means that different works and articles can be discussed during different academic years, even if classes are taught by the same teacher. Although it can be observed that there are some components which are usually on the list of required literature. This is due to the fact that every lecturer, during his/her classes, has to familiarize students with the main theories.

The books that are most frequently used by teachers in the field of Political theories include, among others: Aristotle (1984), Politik, in: Politische Philosophie. Ein Lesebuch. Texte, Analysen, Kommentare, eds. E. Braun, F. Heine, U. Opolka, Reinbek; Brokker M. (ed.) (2007), Geschichte des politischen Denkens. Ein Handbuch, Frankfurt/M; Brunkhorst H. (2000), Einführung in die Geschichte politischer Ideen, München; Hobbes T. (1984), Leviatan, in: Politische Philosophie. Ein Lesebuch. Texte, Analysen, Kommentare, eds. E. Braun, F. Heine, U. Opolka, Reinbek; Roth K. (2003), Genealogie des Staates. Prämissen des neuzeitlichen Politikdenkens, Berlin; Weber M. (1984), Politik als Beruf, in: Politische Philosophie. Ein Lesebuch. Texte, Analysen, Kommentare, eds. E. Braun, F. Heine, U. Opolka, Reinbek.

In the area of Political systems and comparison, the use of the following works is common: Glaeßner G.-J. (2006), Politik in Deutschland, Wiesbaden; Rudzio W. (2011), Das politische System der Bundesrepublik Deutschland, Wiesbaden; Schmidt M. G. (2011), Das politische System der Bundesrepublik Deutschlands, Wiesbaden.

In the area of Theory, empiricism and history of international relations, the following works appear: Baylis J., Smith S., Owens P. (eds.) (2011), The Globalization of World Politics, New York; Dunne T., Kurki M., Smith S. (eds.) (2007), International Relations Theories. Discipline and Diversity, Oxford; Jackson R., Sørensen G. (1999), Introduction to International Relations, Oxford; Krell G. (2009), Weltbilder und Weltordnung. Einführung in die Theorie der internationalen Beziehungen, Baden-Baden; Schieder S., Spindler M. (2003), Theorien der Internationalen Beziehungen, Opladen; Schimmelfennig F. (2010), Internationale Politik, Paderborn; Staack M. (eds.) (2012), Einführung in die internationale Politik, München; Wendt A. (1992), Anarchy is what states make of it, The social construction of power politics, "International Organization" no. $46 .{ }^{37}$

After successfully completing studies (gaining 180 LP) students obtain a Bachelor of Arts - BA university degree (Bachelorstudiengang Politikwissenschaft).

\section{Political science bachelor studies curriculum}

\begin{tabular}{|l|c|}
\hline A) BASIC COURSE/KERNFACH & 150 LP \\
\hline 1) Introduction/Einführungsbereich & $\mathbf{2 8 ~ L P}$ \\
\hline $\begin{array}{l}\text { Module: Introduction to political science A/Modul: Einführung in die Politikwissenschaft A } \\
\text { Module: Introduction to methods of scientific work/Modul: Einführung in die Methoden wissen- } \\
\text { schaftlichen Arbeitens }\end{array}$ & 8 \\
$\begin{array}{l}\text { Module: Introduction to qualitative and quantitative methods/Modul: Einführung in qualitative } \\
\text { und quantitative Methoden }\end{array}$ & 10 \\
\hline
\end{tabular}

${ }^{37}$ The inclusion of the book by A. Wendt, one of the most famous constructivists in the theory of international relations, in the list of literature illustrates the current direction of the research institute. 


\section{2) Basic area I/Grundlagenbereich I}

Basic Module: Political theory/Grundlagenmodul: Politische Theorie

Basic module: Political systems and comparison/Grundlagenmodul: Politische Systeme und Vergleich

Basic module: Theory, empiricism and history of international relations/Grundlagenmodul: Theorie, Empirie und Geschichte der internationalen Beziehungen

Basic module: Legal and philosophical foundations of politics/Grundlagenmodul: Rechtliche und philosophische Grundlagen der Politik

Basic module: International political economy/Grundlagenmodul: Internationale Politische Ökonomie

Basic module: Political sociology/Grundlagenmodul: Politische Soziologie

Basic module: Analysis of the policy area, including environmental policy/Grundlagenmodul:

Politikfeldanalyse, insbesondere Umweltpolitik

Basic module: Study of peace and war/Grundlagenmodul: Friedens- und Konfliktforschung

Basic Module: European integration/Grundlagenmodul: Europäische Integration

Basic module: Analysis of regional policy/Grundlagenmodul: Regionale Politikanalyse

\section{4) Optional area/Wahlbereich}

\section{a) Spezialisierungsbereich}

Specialist Module: Political theory/Spezialisierungsmodul: Politische Theorie

Specialist Module: Political systems and comparison/Spezialisierungsmodul: Politische Systeme und Vergleich

Specialist Module: International relations/Spezialisierungsmodul: Internationale Beziehungen

Specialist Module: Legal and philosophical foundations of politics/Spezialisierungsmodul:

Rechtliche und philosophische Grundlagen der Politik

Specialist Module: International political economy/Spezialisierungsmodul: Internationale Politische Ökonomie

Specialist Module: Political sociology/Spezialisierungsmodul: Politische Soziologie

Specialist Module: Analysis of the policy area, including environmental policy/Spezialisierungsmodul: Politikfeldanalyse, insbesondere Umweltpolitik

Specialist Module: Study on peace and war/Spezialisierungsmodul: Friedens- und Konfliktforschung

Specialist Module: European integration/Spezialisierungsmodul: Europäische Integration

Specialist Module: Analysis of regional policy/Spezialisierungsmodul: Regionale Politikanalyse

b) Modules of tangential areas/Module des Affinen Bereichs (für jede 10 LP)

5) Deeper area/Vertiefungsbereich

Module: Deeper - Political theories/Modul: Vertiefung - Politische Theorie

Module: Deeper - Political systems and comparison/Vertiefung - Politische Systeme und Vergleich

Module: Deeper - International relations/Modul: Vertiefung - Internationale Beziehungen

6) Colloquium and Bachelor's thesis/Bachelorarbeit mit begleitendem Kolloquium

B) GENERAL AREA OF PROFESSIONAL PREPARATION/STUDIENBEREICH ALLGEMEINE BERUFSVORBEREITUNG (ABV)

1) Professionally oriented modules in the area of additional qualifications/Module zur Berufsfeldorientierung im Kompetenzbereich Fachnahe Zusatzqualifikationen

Planning and management/Planung und Verwaltung

Politico-scientific consultancy and political mediation/Politikwissenschaftliche Beratung und Politikvermittlung

Political education of adults/Politische Erwachsenenbildung

International service/Internationale Dienste

2) Modules selected among other areas of competence/Frei wählbare Module in anderen Kompetenzbereichen (für jede 5 LP) 


\section{Science of Politics at Humboldt University}

The Institute of Social Sciences - ISW ${ }^{38}$ - at the Humboldt University, as part of the Faculty of Philosophy III, ${ }^{39}$ was created in 1993. Its profile is characterized by several key elements, such as the integration of sociology and political science as a modern empirical social science which has not forgotten classic theoretical methods, focusing on political and social institutions, as well as social problems, the considered and consistent application of sociological methods in the empirical comparison of societies and political systems and analysis of the socio-political significance of sociological research, linked to an open dialogue between teachers, students, social and political actors. The main subjects of teaching and research at ISW are democratic decision-making processes, effects and changes in the political and social institutions, processes of democratization and un-democratization, different types of power, theories of political power, legitimacy and the overthrow of power, domination and symbolic domination, social structures, social inequalities and social inclusion in the context of work, gender, family, migration, urban and demographic development, and the cultural, social and political divisions of societies and their implications for social and political activities (Über das ISW).

Sixteen professors of political science and sociology, and guest professors, associate professors and other teachers are responsible for teaching and research at the Institute (Über das ISW). Their research effects are published as a series of "Working Papers" (Working Paper Series). In the years 1994-2012 political scientists could publish their articles on pages of the journal "Humboldt-Spectrum" (Profile der Zeitschrift).

The Institute offers several majors combining social sciences with political sciences. They have been very highly rated in the Ranking of Excellence conducted by CHE in 2012/2013 (CHE). Furthermore, according to the ranking carried out in 2007, which was attended by members of DVPW and DGfP, HU received 1st place in Political theories, political philosophy and history of ideas (IX., 5. Die Reputation von Universitäten und Forschungsstätten, p. 154).

Political science was combined with sociology and formed the Social Sciences major in the academic year 2002/2003. The aim of the studies is to provide basic knowledge and research methods of both disciplines. The emphasis is placed on the transfer of broad and integrated knowledge and understanding of the key theories and methods, on critical reflection relating current knowledge and research (basic modules). Students (especially in the context of deeper and optional modules) acquire the theoretical, methodological and practical skills and competencies for further development and the use of theoretical knowledge and ability to solve theoretical problems. Also they acquire the ability to formulate and defend their opinions and views. This is done through lectures, virtual education, independent and shared learning (Studien, § 4 of the herb des Studiums, Internationalität).

Successful completion of the studies enables students to work in different social areas such as economy, governance, social and political organizations and media. Another advantage is the possibility of taking modules abroad (students are encouraged to travel abroad in the 3rd, 4th or 5th semester of studies) (Studien).

38 Institut für Sozialwissenschaften - ISW.

39 Since summer 2014, the Philosophische Fakultät III has been renamed the Faculty of Cultural-, Social- and Education Sciences (Kultur-, Sozial- und Bildungswissenschaftliche Fakultät). 
A Bachelor's Degree majoring in Social Sciences consists of interrelated areas: a Compulsory area and an Optional area, which consists of Compulsory optional area I and Compulsory optional area II (a student must obtain 140 points from both $\left(\mathrm{SP}^{40}\right)$ ). This system also includes General studies, which covers activities in other fields or classes offered in optional modules in the Social science major (10 SP). They serve deepening and complementing the expertise, to create an individual student's educational profile. In addition, students must obtain Additional professional qualifications (30 SP). Thanks to the 8-week practices and classes offered by qualified practitioners, students gain an insight into professional activities (Studien).

The objectives, content and structure of these studies and additional professional qualifications are governed by separate regulations. The structure and course of study is described in the university regulations, containing detailed descriptions, the content and learning objectives of each module, and a sample study plan. Each module is described point by point, as well as working time in hours during the full study is specified (Studien).

Neither the study regulations nor other documents define the canon of literature compulsory for students of a Social sciences bachelor. Each teacher individually chooses the books and articles that are used and discussed in class and required for exams. This means that even if classes are taught by the same teacher, different works and articles can be discussed during different academic years. Although there are some titles which are usually on the list of required literature. This is due to the fact that the Institute of Social Sciences does not identify itself with only one of the traditional "schools," or with one of the traditional research theories, in practice, each teacher during his/her classes is supposed to familiarize students with the main theories.

The works that are most frequently used by teachers in the area of Political theories include: Aristotle (1989), Politik: Schriften zur Staatstheorie, ed. F. F. Schwarz, Stuttgart; Brodocz A., Schaal G. S. (eds.) (2002), Politische Theorien der Gegenwart. Eine Einführung, vol. 1 and 2, Opladen; Beyme K. (2000), Die politischen Theorien der Gegenwart. Eine Einführung, Wiesbaden; Beyme K. (1999), Theorie der Politik im 20. Jahrhundert. Von der Moderne zur Postmoderne, Frankfurt/M; Hobbes T. (1976), Leviathan. Oder Stoff, Form und Gewalt eines bürgerlichen und kirchlichen Staates, ed. I. Fetscher, Frankfurt a. M.-Berlin-Wien.

In the compulsory area of the Political system of the FRG there are titles such as: Glaeßner G.-J. (2006), Politik in Deutschland, Wiesbaden; Rudzio W. (2011), Das politische System der Bundesrepublik Deutschland, Wiesbaden; Schmidt M. G. (2011), Das politische System der Bundesrepublik Deutschland, Wiesbaden; Sturm R., Pehle H. (2005), Das neue deutsche Regierungssystem, Wiesbaden; Böhret C., Jann W., Kronenwett E. (1979), Innenpolitik und politische Theorie: Ein Studienbuch, Opladen; Ismayr W. (2003), Die politischen Systeme Westeuropas im Vergleich, in: Die politischen Systeme Westeuropas, ed. W. Ismayr, Opladen.

In the area of comparative Political science and international relations the following works appear: Bull H. (1985), Die anarchische Gesellschaft, in: Weltpolitik: Strukturen Akteure-Perspektiven, eds. K. Kaiser, H.-P. Schwarz, Stuttgart; Huntington S. P. (1991),

${ }^{40}$ Studienpunkte - SP. 
The Third Wave. Democratization in the Late Twentieth Century, London; Lane J. E., Ersson S. (1999), Politics and Society in Western Europe, London; Lijphart A. (1999), Patterns of Democracy, New Haven-London; Müller H. (2000), Internationale Regime und ihr Beitrag zur Weltordnung, in: Weltpolitik im neuen Jahrhundert, eds. K. Kaiser, H.-P. Schwarz, Bonn; Münkler H. (2002), Die neuen Kriege, Reinbek; Schwarz H.-P. (1985), Der Faktor Macht im heutigen Staatensystem, in: Weltpolitik: Strukturen - Akteure-Perspektiven, eds. K. Kaiser, H.-P. Schwarz, Stuttgart.

After successfully completing the studies (gaining $180 \mathrm{SP}$ ) students obtain a Bachelor of Arts - BA university degree (Studien, \& 9 Studienabschluss Gesamtnote, Akademischer Grad).

\section{Social Sciences bachelor studies curriculum}

\begin{tabular}{|c|c|}
\hline A) BA/MONOFACH & $140 \mathrm{SP}$ \\
\hline 1) Compulsory area/Pflichtbereich & $100 \mathrm{SP}$ \\
\hline $\begin{array}{l}\text { - Module 1: Introduction to social studies/Modul 1: Einführung in das Studium der Sozialwis- } \\
\text { senschaften } \\
\text { - Module 2: Sociological theories/Modul 2: Soziologische Theorien } \\
\text { - Module 3: Political theories/Modul 3: Politische Theorien } \\
\text { - Module 4: Microsociology and demography/Modul 4: Mikrosoziologie und Demographie } \\
\text { - Module 5: Political system of the FRG/Modul 5: Politisches System der BRD } \\
\text { - Module 6: Comparative political science and international relations/Modul 6: Vergleichende } \\
\text { Politikwissenschaft und Internationale Beziehungen } \\
\text { - Module 7: Social structure and diversification/Modul 7: Sozialstruktur und Diversität } \\
\text { - Module 8: Methods of empirical social research I/Modul 8: Methoden empirischer Sozialfor- } \\
\text { schung I } \\
\text { - Module 9: Methods of empirical social research II/Modul 9: Methoden empirischer Sozialfor- } \\
\text { schung II } \\
\text { - Module 10: Methods of empirical social research III/Modul 10: Methoden empirischer Sozial- } \\
\text { forschung III } \\
\text { - Module 15: Final module (Bachelor thesis)/Modul 15: Abschlussmodul (Bachelorarbeit) }\end{array}$ & $\begin{array}{r}8 \\
8 \\
10 \\
10 \\
10 \\
15\end{array}$ \\
\hline 2) Optional area/Wahlbereich & $40 \mathrm{SP}$ \\
\hline a) Compulsory optional area I:/Wahlpflichtbereich I: & $20 \mathrm{SP}$ \\
\hline $\begin{array}{l}\text { - Deeper Module 11/1: Politics and governance in multilevel systems/Modul Vertiefung 11/1: } \\
\text { Politik und Regieren im Mehrebenensystems } \\
\text { - Deeper Module 11/2: Comparative political science and international relations/Modul Vertie- } \\
\text { fung 11/2: Vergl. PW und Intern. Beziehungen } \\
\text { - Deeper Module 11/3: Gender, family and work/Modul Vertiefung 11/3: Gender, Familie und } \\
\text { Arbeit } \\
\text { - Deeper Module 11/4: State and heterogeneity/Modul Vertiefung 11/4: Stadt und Heterogeni- } \\
\text { tät } \\
\text { - Deeper Module 11/5: Political sociology/Modul Vertiefung 11/5: Politische Soziologie } \\
\text { - Deeper Module 11/6: Sociological and political-science theories/Modul Vertiefung 11/6: So- } \\
\text { ziologische und politikwissenschaftliche Theorien }\end{array}$ & $\begin{array}{l}10 \\
10 \\
10 \\
10 \\
10 \\
10\end{array}$ \\
\hline $\begin{array}{l}\text { b) Compulsory optional area II:/Wahlpflichtbereich II: } \\
\text { (Aus den im Modul } 12 \text { angebotenen Seminaren sind } 4 \text { - je } 2 \text { SWS und je } 5 \mathrm{SP} \text { - zu wählen } \\
(\text { gesamt } 20 \mathrm{SP}) \text { ) }\end{array}$ & $20 \mathrm{SP}$ \\
\hline B) GENERAL STUDIES/STUDIUM GENERALE & $10 \mathrm{SP}$ \\
\hline $\begin{array}{l}\text { C) ADDITIONAL PROFESSIONAL QUALIFICATIONS/BERUFSBEZOGENE ZU- } \\
\text { SATZQUALIFIKATIONEN }\end{array}$ & $30 \mathrm{SP}$ \\
\hline TOTAL/INSGESAMT & $180 \mathrm{SP}$ \\
\hline
\end{tabular}




\section{Conclusions}

Political science in Germany is a highly diversified academic major. Both the name and program of study have changed repeatedly. Due to the political situation and different perspectives on what the science is, this major disappeared and appeared several times from universities and colleges, it also was not always an independent subject. From the division of Germany after World War II, political science permanently established itself in the courses of study offered in the Federal Republic of Germany, but it was not until the reunification of the country that it was allowed to exist in the former German Democratic Republic. Starting from this point, it has developed quite well, as illustrated by the fact that it has gained good placings in prestigious rankings conducted by the Centre for Higher Education Development or members of the German Association of Political Science and the German Union of Political Science.

After reunification, the former East German universities hired West German professors and accepted the division into four Chairs - Political theory and the history of ideas, German system of government, International politics and German foreign policy - as well as the understanding of political science as democratic. At the moment, this division is not always visible, because universities have broad competences, which includes their determining courses of study and the activities taking place within academic society. As a result, there are very many variants of political science studies - for instance the University of Potsdam offers three Bachelor majors (Politics and Administration, Politics, Administration and Organization, Politics and Economy), and the Free University of Berlin and Humboldt University offer only one major each (Political Science and Social Sciences respectively). Although the names are different, all of them are united by their interdisciplinary program offer.

Universities set their own rules of study, which vary in individual institutions, although they must be approved by the appropriate State of Germany and must not be in conflict with the law of this state - for example, Humboldt University and Free University of Berlin, even though being under Berlin's jurisdiction, require a completely different number and type of exam passes and points required. Moreover, even political science majors offered within a single University differ in this aspect - such as the University of Potsdam, which is under Brandenburg's jurisdiction. In addition, German political scientists working at universities have wide freedom in determining the themes of their classes. However, they must harmonize with the field of study (especially if classes are offered as part of the basic modules) and the research area of lecturers. Placing great emphasis on teaching students to think independently, to be able to express and defend their own opinions - these facts still remain a common element.

German universities place great importance on the labor market. In principle, they also have an obligation to adapt to the changing realities of the labor market, therefore they place great emphasis on training and apprenticeships. The Faculty of Economic and Social Sciences of the University of Potsdam, Otto Suhr Institute of the Free University of Berlin and the Institute of Social Sciences at Humboldt University praise their political science majors as closely cooperating with the policy, management, economy and society related sectors, and as ensuring the good preparation of students to find work in many different areas, institutions and organizations. 
Political scientists employed at universities have many opportunities to publish and create political science magazines associated with universities. Since 1971 academics from the Otto Suhr Institute have edited the journal "PROKLA. Zeitschrift für kritische Sozialwissenschaft" issued to the present day. Moreover, in the seventies, they were allowed to publish in "Sozialistische Politik (1969)." In turn, the political scientists of the University of Potsdam, in cooperation with the scientific staff of the Western Institute, have, since 1993, issued the magazine "WeltTrends." Until 2012 political scientists affiliated with the Institute of Social Sciences were able to publish their research in the general academic "Humboldt-Spectrum," at the moment their research is published as a series of "Working Papers," because they have not set up their own political science journal. As most political scientists employed at the aforementioned universities belong to the German Union of Political Science and/or to the German Association of Political Science, they can also distribute their scientific achievements in the journal issued since 1960 by DVPW "Political Vierteljahresschrift - PVS," in "Politikwissenschaft. Rudnbrief der Deutschen Vereinigung für Politische Wissenschaft" and in a series issued by DGfP since 1988 "Veröffentlichungen der Deutschen Gesellschaft für Politikwissenschaft (DGfP)." Analyzing the research profile of these journals and publications it can be concluded that academics from the Otto Suhr Institute, up until the nineties, mostly identified themselves with the critical-dialectical theory, and later with empirical-analytical, and also constructivist theories. Political scientists from the Faculty of Economic and Social Sciences and the Institute of Social Sciences use the entire range of research theories, though the empirical-analytical approach seems to be the most respected.

University units which host bachelor of political science degrees do not arbitrarily define the compulsory literary canon for students of these majors. In practice, each teacher working at the Faculty of Economic and Social Sciences, at the Otto Suhr Institute and the Institute of Social Sciences selects the literature which is used during classes and required to pass the exam or obtain a credit. This means that in different academic years different works and articles can be discussed and analyzed, even if classes are taught by the same teacher. The study and comparison of required literature for lectures of three mandatory areas - Political theories, Political systems/Political system of Germany and Politics/international relations - reveals that some of the items are used in the faculty, as well as in both institutes. These are, respectively: Aristotle, Politik; Hobbes T., Leviathan; Weber M., Politik als Beruf; Glaeßner G.-J., Politik in Deutschland; Rudzio W., Das politische System der Bundesrepublik Deutschland; Schmidt M. G., Das politische System der Bundesrepublik Deutschlands; Baylis J., Smith S., The Globalization of World Politics. An Introduction to International Relations; Schieder S., Spindler M., Theorien der Internationalen Beziehungen. Furthermore, the research showed that there are also some names present that are held in high esteem in the faculty or in one of these institutes. Those names appearing on the literature lists are: K. Beyme, H. Brunkhorst, A. Liphardt, H. Münkler, T. Risse, K. Roth, F. Schimmelfennig and A. Wendt. Those authors, some of whom are also lecturers at the universities discussed in the paper, have contributed significantly to the development of research into theories and political systems or even into international relations. 


\section{Bibliography}

Bachelor of Science Politik \& Wirtschaft, http://www.uni-potsdam.de/wiso/studium/bachelor/bsc-politik-und-wirtschaft.html, 15.12.2014.

Bachelor Politik und Verwaltung, http://www.uni-potsdam.de/wiso_dekanat/deutsch/Studium/Studiengaenge/BAPuvneu, 15.12.2014.

Bachelor Politik, Verwaltung und Organisation, http://www.uni-potsdam.de/wiso/studium/bachelor/ ba-politik-verwaltung-und-organisation.html, 15.12.2014.

Bachelorstudiengang Politikwissenschaft, http://www.polsoz.fu-berlin.de/studium/studiengaenge/ba_ studiengaenge/ba_politikwissenschaft/index.html, 15.12.2014.

Berg-Schlosser D., Stammen T. (2003), Einführung in die Politikwissenschaft, München.

Berliner Hochschulgesetz, Verkündungsstand: 26.09.2014 in Kraft ab: 03.06.2011, http://gesetze.berlin.de/default.aspx?vpath=bibdata\%2Fges\%2FBlnHG\%2Fcont $\% 2 \mathrm{FB} \operatorname{lnHG} \% 2 \mathrm{EP} \%$ 2Ehtm, 15.12.2014.

Bleek W. (2001), Geschichte der Politikwissenschaft in Deutschland, München.

Brandenburgisches Hochschulgesetz (BbgHG) vom 28. April 2014 (GVBl.I/14, [Nr. 18], http://www.bravors.brandenburg.de/sixcms/detail.php?gsid=land_bb_bravors_01.c.54908.de\#25, 15.12.2014.

Buckel S., Fischer-Lescano A., Hanschmann F., Die Geburt der Kritischen Justiz aus der Praxis des Widerständigen, http://www.kj.nomos.de/fileadmin/kj/doc/Aufsatz_KJ_08_03.pdf, 15.12.2014.

CHE Excellence Ranking, http://www.che-ranking.de/cms/?getObject=632\&getLang=en, 15.12.2014.

Details zur Reihe Veröffentlichungen der Deutschen Gesellschaft für Politikwissenschaft (DGfP), http:// www.nomos-shop.de/reihenpopup.aspx?reihe=269, 20.12.2014.

Detjen J., Ferdinand A. Hermens (1906-1998), http://www.nomos-elibrary.de/index.php?doi=10.5771 /9783845241982_347, 15.12.2014.

Deutsche Gesellschaft für Politikwissenschaft, Veröffentlichungen, http://www.dgfp.org/vero.html, 20.12.2014.

Die Anfänge der Kölner Politikwissenschaft, http://www.politik.uni-koeln.de/geschichte.html, 15.12.2014.

Die Wirtschafts- und Sozialwissenschaftliche Fakultät, http://www.uni-potsdam.de/wiso/, 15.12.2014.

DVPW, Rundbriefe, http://www.dvpw.de/mitgliedschaft/rundbriefe.html, 20.12.2014.

Entstehung und Themen der ,Freiburger Schule”, http://www.eucken.de/de/freiburger-tradition/zurgeschichte-der-freiburger-schule.html, 15.12.2014.

Exzellenzinitiative des Bundes und der Länder zur Förderung von Wissenschaft und Forschung an deutschen Hochschulen, http://www.dfg.de/formulare/exin301/exin301.pdf, 15.12.2014.

Fachgruppe Politik- \& Verwaltungswissenschaft, http://www.uni-potsdam.de/wiso/fakultaet/struktur/ politik-verwaltung.html, 15.12.2014.

Fachspezifische Ordnung 1: Fachspezifische Ordnung für das Bachelorstudium „Politik und Verwaltung " an der Universität Potsdam vom 4. Mai 2011, http://www.uni-potsdam.de/ambek/ambek2011/15/Seite7.pdf, 15.12.2014.

Fachspezifische Ordnung 2: Fachspezifische Ordnung für das Bachelorstudium „Politik, Verwaltung und Organisation " an der Universität Potsdam vom 18. Januar 2012, http://www.uni-potsdam. de/ambek/ambek2012/12/Seite1.pdf, 15.12.2014.

Friedrich C. J., Grundsätzliches zur Geschichte der Wissenschaft von der Politik, in: Zeitschrift für Politik N. F. I (1954).

Geschichte und Profil, http://www.polsoz.fu-berlin.de/polwiss/osi/geschichte_profil/index.html, 15.12.2014.

Heinrich M., PROKLA - oder wie ist heute eine linke, wissenschaftliche Zeitschrift möglich?, http:// www.prokla.de/uber-uns/, 20.12.2014. 
Hochschulrahmengesetz in der Fassung der Bekanntmachung vom 19. Januar 1999 (BGBl. I S. 18), das zuletzt durch Artikel 2 des Gesetzes vom 12. April 2007 (BGBl. I S. 506) geändert worden ist, http://www.gesetze-im-internet.de/bundesrecht/hrg/gesamt.pdf, 15.12.2014.

Lothar P. (2014), Marx an die Uni. Die „Marburger Schule“-Geschichte, Probleme, Akteure, Köln.

Naßmacher H. (2010), Politikwissenschaft, Oldenbourg.

Politikwissenschaft, $\quad$ http://www.bpb.de/nachschlagen/lexika/handwoerterbuch-politisches-system/40353/politikwissenschaft?p=all, 15.12.2014.

Politikwissenschaft - Mono-Bachelor, http:/www.fu-berlin.de/studium/studienangebot/grundstaendige/politik_mono/index.html, 15.12.2014.

Politische Vierteljahresschrift, http://www.pvs.nomos.de/, 20.12.2014.

Profil der Zeitschrift, https://www.hu-berlin.de/forschung/szf/forschungsmanagement/veroeffentlichungen/spektrum/fowphspr_html, 20.12.2014.

PROKLA Zeitschrift für kritische Sozialwissenschaft, http://www.prokla.de/jahrgange/, 20.12.2014.

Prüfungen und Abschlüssen (Hochschulprüfungsverordnung - HSPV) vom 07. Juni 2007 (GVBl.II/07, [Nr. 12], S.134), zuletzt geändert durch Verordnung vom 15. Juni 2010 (GVBl.II/10, [Nr. 33]), http://www.bravors.brandenburg.de/sixcms/detail.php?gsid=land_bb_bravors_01.c.43393.de, 15.12.2014.

Prüfungsordnung des Fachbereichs Politik und Sozialwissenschaften der Freien Universität Berlin für den Bachelorstudiengang Politikwissenschaft und das 60-Leistungspunkte-Modulangebot Politikwissenschaft im Rahmen anderer Studiengänge, http://www.fu-berlin.de/service/zuvdocs/ amtsblatt/2012/ab682012.pdf?1404215795, 15.12.2014.

Schlüsselkompetenzen 1: Schlüsselkompetenzen, http://www.uni-potsdam.de/wiso/studium/bachelor/ ba-politik-verwaltung-und-organisation/schluesselkompetenzen.html, 15.12.2014.

Schlüsselkompetenzen 2: Schlüsselkompetenzen, http://www.uni-potsdam.de/wiso/studium/bachelor/ bsc-politik-und-wirtschaft/schluesselkompetenzen.html, 15.12.2014.

Studieninformationen Sozialwissenschaft, http://www.sowi.hu-berlin.de/studium/downloads/studieninformationsheft, 15.12.2014.

Studienordnung des Fachbereichs Politik und Sozialwissenschaften der Freien Universität Berlin für den Bachelorstudiengang Politikwissenschaft und das 60-Leistungspunkte-Modulangebot Politikwissenschaft im Rahmen anderer Studiengänge, http://www.fu-berlin.de/service/zuvdocs/ amtsblatt/2012/ab682012.pdf?1404215795, 15.12.2014.

Studien- und Prüfungsordnung für das Bachelorstudium im Fach Sozialwissenschaften, Monofach und Beifach im Monostudiengang, Zweitfach im Kombinationsstudiengang, https://www.amb.huberlin.de/2011/36/362011, 15.12.2014.

Studienziele 1: Studienziele \& Aufbau des Studiums, http://www.uni-potsdam.de/wiso/studium/bachelor/ba-politik-und-verwaltung/studienziele-aufbau-des-studiums.html, 15.12.2014.

Studienziele 2: Studienziele \& Aufbau des Studiums, http://www.uni-potsdam.de/wiso/studium/bachelor/ba-politik-verwaltung-und-organisation/aufbau.html, 15.12.2014.

Studienziele 3: Studienziele \& Aufbau des Studiums, http://www.uni-potsdam.de/wiso/studium/bachelor/bsc-politik-und-wirtschaft/studienziele-aufbau-des-studiums.html, 15.12.2014.

Über das ISW, https://www.sowi.hu-berlin.de/institut/ueber, 15.12.2014.

Über den SFB, http://www.sfb-governance.de/ueber_uns/index.html, 15.12.2014.

Wefers U. (2007), Hochschulmarketing in Deutschland: Chancen und Herausforderungen, Hamburg. WeltTrends, http://welttrends.de/profil-polnisch/, 20.12.2014.

Working Paper Series, https://www.sowi.hu-berlin.de/lehrbereiche/politikundverwaltung/wps/workingpaperseries, 20.12.2014.

Verordnung über die Gestaltung von Prüfungsordnungen zur Gewährleistung der Gleichwertigkeit von Studium, Prüfungen und Abschlüssen (Hochschulprüfungsverordnung - HSPV) vom 07. 
Juni 2007 (GVBl.II/07, [Nr. 12], S.134), zuletzt geändert durch Verordnung vom 15. Juni 2010 (GVBl.II/10, [Nr. 33]), http://www.bravors.brandenburg.de/sixcms/detail.php?gsid=land_bb_ bravors_01.c.43393.de, 15.12.2014.

IX. Beiträge unserer Mitglieder, J. Falter, M. Knodt, Die Bedeutung von Themenfeldern, theoretischen Ansätzen und die Reputation von Fachvertretern, in: Politikwissenschaft. Rundbrief der Deutschen Vereinigung für Politische Wissenschaft 137, Herbst 2007, http://www.dvpw.de/filead$\mathrm{min} /$ docs/Rundbrief137.pdf, 15.12.2014.

\section{Politologia w Republice Federalnej Niemiec - wybrane przykłady}

\section{Streszczenie}

Niniejszy artykuł zarysowuje historię niemieckiej nauki o polityce i jej stan obecny. Zawiera porównanie współczesnych kierunków politologicznych oferowanych przez trzy najlepiej oceniane w niemieckich rankingach uniwersytety - Uniwersytet Poczdamski, Wolny Uniwersytet Berliński i Uniwersytet Humboldta w Berlinie. Przedstawia strukturę studiów politologicznych, rodzaj oferowanych kursów oraz literaturę wykorzystywaną podczas nauczania.

Slowa kluczowe: politologia, nauka, uniwersytet, RFN 
